\title{
Foreword
}

A few years ago, the great contemporary philosopher of technology Andrew Feenberg wrote: "We are well aware that we are a technological society, and not just because we use so many devices but also in our spirit and our way of life."1 $\mathrm{T}$ To be honest, I have never been quite sure to whom this sentence refers, and by this I do not mean simply that there is no such thing as "we" anymore. Even if we (there it is again) accept that "we" means those of us who live in something like the modern way, I am not sure that we generally are "well aware" of what I think is otherwise the basic truth of Feenberg's claim. To be sure, few will have failed to notice that our everyday practices are completely mediated by devices of one sort or another. Some would suggest that such mediation is original and necessary to human experience in any case, and that our awareness of this condition has simply been heightened by the apparent novelty of various digital prostheses. These have prompted anxious popular discussion of the "impact" of digital technology on our "quality of life" in various domains (work, commerce, courtship, parenting, and childhood), but I am not sure this approaches what is contemplated by the suggestion that technology inheres in "our spirit and our way of life." If pressed, I suspect most of us would respond to the question "What sort of society do you live in?" with the answer "a democracy." Of course, here is the rub: most of us so closely identify democracy with technology that we have become unable to distinguish

1 Andrew Feenberg, Heidegger and Marcuse: The Catastrophe and Redemption of History (New York: Routledge, 2005), 6. 


\section{viii Foreword}

between them, or to define either one of them in terms that do not presumptively invoke the other.

The book you now hold in your hands, or see on your screen, aims to correct that, by refusing to collapse the distinction between technology and politics. It seeks to provoke a heightened, critical awareness of just how deep our collective relationship with technology goes, and what is at stake in it. In so doing, it speaks to the cruel irony at the centre of the technological condition: that in our efforts to exercise control over the contingencies that define our existence in the world, we have relinquished our capacity to exert control over the place of technology in our public and private lives. It is not just a matter of the joke that email plays on us ("Here is a great new tool for interpersonal communication that will make you more productive, better organized, and give you tons of free time you never had before!"), but rather that we cannot imagine a way out of our current economic and environmental predicaments that does not involve massive investment in precisely the same technological enterprise that produced the situation in the first place. This, we might say, is the broken heart at the core of David Tabachnick's prescient and insightful book, a broken heart he seeks to mend.

In a radical departure from present orthodoxies in social studies of technology, Tabachnick does not treat technology as a mere ensemble of devices whose meaning derives exclusively from the specific contexts in which their design, application, and use patterns unfold. In the pages that follow, technology is instead presented as a particular way of being in the world that has eclipsed other ways of being in the world. In particular, technology is the prevailing and definitive way people in the frantic countries of industrial, post-industrial, and informational capitalism have come to reckon with the uncertainties the world necessarily presents to them. Tabachnick's concern is for what is overshadowed in this eclipse, and for whether and how it might be brought back into the light. For him, technology is not just a historical or sociological question but, moreover, a deeply philosophical one.

The way of being in the world that has been eclipsed by technology is characterized by routine engagement of the human capacity for practical judgment, a capacity central to the possibility of ethical and political life. The story Tabachnick tells is the history of the contest, declared or otherwise, between techne and phronesis, between the useful arts and the sort of judgment that might direct these towards truly good purposes. It is a story of reversal, in which the priority properly assigned to political and ethical judgment has somehow given way to 
the perceived imperatives of technological development, and it is a story about what this turn of events means for our prospects. In this, Tabachnick joins a long line of storytellers who have tried in various ways to narrate the technological predicament - Heidegger, Marcuse, Ellul, Illich, Grant, Winner, Borgmann - thinkers on whose shoulders he stands but beyond whose historical horizons he clearly sees. For, whatever truth there might be to claims that human beings have been technological since they first engaged productively with the world outside themselves, it is hard to deny that the extent and intensity of contemporary technological activity lends a distinctive practical urgency to the question of how we are to live with the technologies we make, and that make us what we are.

As Tabachnick puts it, "Somewhere along the line we began to relinquish the deeply rooted intellectual and practical capacities that allow us to understand and regulate the role of technology in our lives." The primary endeavour here is, accordingly, forensic: when, where, and how did it happen, and who did it? Tabachnick's signature proposition, substantiated by a magnificent tour through the history of Western political thought, is that "our idea about technology and how it has changed is largely responsible for the creation and growth of our technological society." This central motif will undoubtedly provoke as many readers as it convinces, for the claim that our idea about a thing - especially as rendered in philosophical texts - determines the reality of that thing in the world fairly cries out for critical confrontation. This goes double for something as irreducibly material as technology. Nevertheless, this is Tabachnick's bold gambit, and the careful manner in which he pursues it should be enough to make serious readers reflect upon why they think what they do about the technology that surrounds them. Tabachnick's sober, sobering, and detailed attention to the material challenges of contemporary technology confirm that he does not imagine that we can do away with technology simply by doing away with the thought of it, as materialist critics might otherwise be inclined to charge. Instead, like all autopsies, his forensic treatment of the career of technology in Western political thought might be exactly what we need to get past the tragedy that put the body on the table, and to move on in light of what we have learned about what has brought us here.

DARIN BARNEY Canada Research Chair in Technology \& Citizenship McGill University 
This page intentionally left blank 